BUZOVERYA A. G. Analysis of the results of the stage control of the evaluation of the technical preparation level of the cheerlidirs-flyers after the implementation of the experimental.

The study of the level of technical readiness of flyer cheerleaders was determined by the control tests we selected, which were combined into four groups of complex criteria: basic cheerleading movements, cheer-jumps, complexity of flyer positions, technical execution of acrobatic elements.

In turn, these complexes contained the following tests: "basic movements" and "dance communication"; "To-Touch", "Pipe" and "Around the World"; "Main Stand", "Steg", "Liberty", "Flag", and "Scorpio"; "Forward", "overturn", "handstand", "sideways", "Randat", "gymnastic", "two-legged", "one-legged", "back-to-back one leg”, "'tempo" revolution forward".

According to the analysis of technical readiness of flyer 9-10 years at the beginning of the experimental procedure, it should be noted that the control and experimental groups at the intragroup level had no significant differences on the Student's $t$-test $(p \geq 0.05)$, implementation of the experimental methodology, the level of technical readiness, both in the control and experimental groups, became higher. In the Cheerleading Basic Movement Tests, the control group remained above average (from 4.04 to 4.21), and in the experimental group, the level of grades went from above average to high (from 4.58 to 4, 65); the complex of "Cheer-jumps" tests of the experimental group increased to a high level ("To-Touch" - 4,5; "Pipe" - 4.62; "Around the World" - 4,54); the increase of indicators in the complex of tests "complexity of positions of the flyer" in the experimental group is greater, and than in the control in all tests except the control test - the position of the flyer "Main rack"; the arithmetic mean of acrobatic element performance in the control group corresponds to a level above the average of 6.65 points, and in the experimental group a high level of 8.52 points.

Keywords: cheerleading, cheerleading-base, technical training, technical readiness, special technical training, stage of preliminary basic training.

DOI: https://doi.org/10.31392/NZ-npu-145.2019.03

УДК 37.091.12:005.963.3]:502.13

Гармата О. М., Лазебна О. М., Бондаренко Л. І.

\title{
ЕКОЛОГО-ЕКСКУСРІЙНА ДІЯЛЬНІСТЬ: МЕТОДИЧНИЙ АСПЕКТ
}

Впровадження в Україні європейських стандартів життя і вихід на провідні позииії світу передбачає ряд реформ $і$ програм у всіх сферах суспільного буття. Серед інших вагомим чинником реалізачії Стратегії сталого розвитку $\epsilon$ спрямованість на збереження навколишнього середовища. Реалізація стратегії сталого розвитку потребує екологізації суспільства на всіх рівнях життєдіяльності людини. Об'єктиваџія зазначеного потребує осучасненого прочесуального забезпечення, що грунтується на можливостях методичних, технологічних досягнень суспільного розвитку. Використання еколого-екскурсійного інструментарію із застосуванням інформаційних методів дозволить оптимізувати становлення інтелектуально-когнітивної компоненти особистісного зростання людини, сприятиме формуванню екоцентричного вектору ї̈ світоглядних позицій.

Ключові слова: екологізація, екскурсійний метод, екскурсія, еколого-екскурсійна діяльність, методика проведення екскурсії, інформаційний метод. 
Діяльність, спрямована на усвідомлення людини в потребі збереження, охорони, відтворення природних ресурсів, раціонального природокористування, збереження біорізноманіття, на визначення місця і ролі навколишнього середовища в бутті людини як середовища її існування складає суть екологізації спільноти. Процес прийняття природобезпечних рішень характеризує поведінково-діяльнісну складову екологічної культури. Однак, йому передує підготовчий - інформаційно-аналітичний етап, який враховує характер екологічних знань і місце екологічних цінностей і орієнтацій в ціннісній системі особистості. Таким чином, прийняття рішень не можливе без сфрормованих когнітивного та мотиваційно-ціннісного компонентів екологічної культури [2, 7, 8].

Процесуально важливим $є$ етап інформаційно-когнітивної компоненти. Акцентування й ініціювання проблеми об'єктивує інтерес до неї, мотивує до пізнання й діяльності. На разі, екологізація освіти, просвітництво неперервний процес отримання інформації екологічного змісту на всіх рівнях соціального стану суб'єкта.

Формування уявлень про основні проблеми, фоорми, наслідки, обсяги антропогенної дії на природне середовище мають доповнюватись знаннями щодо способів, засобів, можливостей їх вирішення.

Метою публікації є висвітлення питань методології екологічної освіти і просвітництва у контексті забезпечення реалізації цілей сталого розвитку суспільства.

Про необхідність узгодженого й раціонального співіснування людини і природи йдеться ще у працях В.Вернадського. Викладаючи концепцію "ноосфери", вчений наголошує на екологізації усіх сфер життєдіяльності людини як основи, здатної забезпечити усвідомлення взаємозв'язку в системі “людина-природа".

Як умову збереження, парадигму сучасного етапу суспільного розвитку визначають екологізацію Е. Гірусов та Х. Маринов.

Проблемі екологізації в різних сорерах (виробництва, технологій, освіти тощо) присвячено роботи Р. Гуревич, В. Ільченко, І. Козловська, В. Сидоренко.

Екологізація в освіті, принципи, форми і засоби освітнього процесу опрацьовано вченими О.А.Пруцакова, Г.П.Пустовіт, Н. А. Пустовіт, О. Колонькова, Н. Левчук.

Питанням організації екскурсійної діяльності присвячено роботи В. К. Барабицька, С. М. Голубнича, А. Я. Короткова, О. Ю. Малиновська, М. М. Поколодна, С. І. Попович, В. К. Федорченко, М. І. Чагайда та інші.

Завдання передбачає розвідку i опрацювання матеріалу щодо використання еколого-екскурсійної діяльності для фрормування екологічної компоненти особистості за допомогою інформаційних методів.

Екологічні негаразди сьогодення не варто сприймати як проблеми, власне, природного середовища. У своїй генезі й наслідках вони $\epsilon$ проблемами суспільства, людини, її історії, умов життя, відношення до світу й реальної дійсності, економічних, культурних і політичних переконань. Сімнадцять цілей Стратегії сталого розвитку спрямовані на подолання й 
оптимізацію існуючої проблеми задля життя майбутніх поколінь [5, 7, 8, 9].

Соціальні запити сьогодення передбачають гармонізацію екологічної, економічної, соціальної складових суспільного розвитку. Загалом, екологізація суспільства $є$ парадигмою сьогодення. Водночас інновації технологічного поступу вимагають осучаснення підходів, розробки відповідного методикометодологічного інструментарію, розрахованого на широкий загал населення різного соціального прошарку, вікового цензу й освітнього ступеня.

Як відомо, нову інформацію ми засвоюємо приблизно в таких пропорціях:

- $10 \%$ того, що ми читаємо,

- 20\% того, що ми чуємо (аудіо-візуальний метод),

- 30\% того, що ми бачимо (демонстрування),

- 50\% того, що ми чуємо і бачимо,

- $70 \%$ того, що ми говоримо,

- 90\% того, що ми говоримо, коли ще й діємо [1, 2].

Така статистика свідчить про ефективність використання методів і методик, що дозволяють задіяти максимально органолептичні сенсори людини і впливати на емоційно-ціннісні показники особистості, а, також, активні, діяльнісні технології впливу.

Екскурсійний метод розглядають як сукупність тематично спрямованих методичних прийомів, в основі яких - проведення екскурсії. Поняття екскурсія формулюють як цілеспрямований, наочний процес пізнання навколишнього середовища (М. П. Анциферов, Л. Бархаш, В. О.Герд, Б. Е. Райков, Л. Ф. Родін, Ю. Е. Соколовський та інші). Метою екскурсії в широкому розумінні $€$ розвиток особистості, водночас - це і отримання знань, інформації про досліджуваний об'єкт [6]. Методично екскурсія характеризується:

- спрямованістю на вивченні головного в обраній тематиці, виборі найвагомішого об'єкта спостереження;

- дослідженні й засвоєнні учасниками нової інформації за умови узгодження її з попередньо отриманим досвідом і знаннями суб'єкта;

- предметність і наочність екскурсії $€$ запорукою аргументації й доказовості отримання інформації;

- огляд чи показ обов'язково супроводжує розповідь. Бажано перевагу надавати зоровому компоненту. Озвучене є тільки коментарем до показу;

- принцип комплексності, природовідповідності оптимізує взаємодію трьох компонентів - екскурсовода, екскурсійних об'єктів та екскурсантів;

- екскурсія характеризується моторністю, руховою активністю;

- важливо враховувати можливість впливу на всі органолептичні сенсори сприйняття навколишнього світу людиною $[1,2,4,6]$.

Організація надання екскурсійних послуг починається з вивчення ринку екскурсійного маркетингу. Саме ринок виявляє потреби суспільства, диктує основні поведінкові й діяльнісні тренди, в тому числі і щодо екскурсійних процесів. Сучасні світові тенденції актуалізують необхідність екологоекскурсійної діяльності. В основі технологічного процесу створення нової екскурсії - розробка екскурсійної методики.

Екскурсійна методика, насамперед, це - сукупність чітких правил та 
вимог, здатних забезпечити реалізацію цілей і призначення екскурсії. Підготовка і проведення екскурсії - взаємообумовлені процеси. Неможливо забезпечити високу якість проведення екскурсії за невиваженою підготовкою $[3,4]$.

Створення нової екскурсії за будь-якою темою - складний трудомісткий технологічний процес.

Предмет екскурсійної методики - цілеспрямоване вивчення, систематизація, формулювання та застосування на практиці методів і засобів виховання, а також методичних прийомів, за допомогою яких екскурсійні працівники здійснюються свою діяльність.

Підготовка екологічної екскурсії включає декілька етапів.

Зокрема, етапи підбору і формування тексту і змісту екскурсії включають:

1) попередню роботу - підбір матеріалів, їх вивчення, відбір об’єктів, які стануть основою екскурсії;

2) розробку екскурсії: складання екскурсійного маршруту, обробку фактичного матеріалу; роботу над змістом екскурсії, її основною частиною (підтеми і основні питання кожної з них);

- підготовку контрольного тексту екскурсії;

- роботу над методикою проведення екскурсії;

- вибір найбільш ефективних методичних прийомів показу і розповіді та кращих точок, ракурсів огляду об’єктів показу;

- підготовка методичної розробки екскурсії, технологічної карти і схеми маршруту (для транспортної екскурсії), “портфеля екскурсовода” [6].

Розробки екскурсії включає 11 етапів: підготовка теми і мети; вивчення і накопичення матеріалу; організація консультацій, виявлення і конкретне визначення екскурсійних об'єктів, складання маршруту екскурсії, об’їзд/обхід маршруту, складання тексту екскурсії, побудова екскурсії, складання карток екскурсійних об’єктів, складання методичної розробки екскурсії, проведення пробної екскурсії.

Крім зазначених етапів доцільно додати ще один - рекламний. Для просування екскурсійних послуг рекомендується використовувати методи особистих рекламних звернень до потенційних клієнтів, посередників та організацій-споживачів екскурсійних послуг й застосування традиційні види інформаційної реклами. В світлі розвитку інноваційних технологій також ефективним буде використовувати мережу Інтернет для залучення потенційних екскурсантів.

У найпростішому вигляді схема всіх екскурсій, незалежно від теми, виду й форми проведення, однакова: вступ, основна частина, висновок.

Вступ, зазвичай, складається з двох частин:

- організаційної (знайомство екскурсовода з групою, групи з водієм та інструктаж екскурсантів щодо правил безпеки й поведінки на маршруті);

- інформаційної (коротке повідомлення про тему та основні об'єкти, довжину й тривалість маршруту, час відправлення й прибуття назад, санітарні зупинки й місце закінчення екскурсії, виходи екскурсантів до об’єктів).

Вступ повинен бути в інформаційній частині яскравим і таким, щоб відразу 
привернути увагу екскурсантів, викликати їх інтерес до теми та об'єктів екскурсії.

Організаційна частина навпаки має бути лаконічною та корисною за змістом. Вступ як початок екскурсії - доволі відповідальний момент, саме під час вступу у екскурсантів виникають перші враження про екскурсовода, відбувається емоційне налаштування, створюється психологічний клімат у колективі.

Основна частина (власне екскурсія) - будується на певних екскурсійних об'єктах, сполученні показу й розповіді. ІІї зміст складається з підтем (від 5 до 12). Підтема - складова частина теми, яка висвітлює декілька пов'язаних між собою питань. Кожна підтема викладається на конкретних об'єктах (одному або декількох) і зі свого боку розподіляється на окремі питання. Їхня кількість зазвичай не перевищує трьох-п'яти. Підтеми надають екскурсії чітке тематичне розділення, визначають співрозмірність окремих її частин. Підтеми послідовно розкривають тему відповідно до внутрішньої логіки матеріалу екскурсії. 3 кожної підтеми в екскурсії обов'язково робляться висновки, а також складається текст логічного переходу до наступної підтеми. Кількість підтем в екскурсії залежить від теми, наявності екскурсійних об'єктів, цільової екскурсійної аудиторії.

Висновок - підсумок з усієї екскурсії, як і вступ складається з двох частин:

- підсумкова - подається підсумок основного змісту екскурсії, висновок за темою загалом - екскурсовод узагальнює побачене і почуте, нагадує екскурсантам основні об’єкти та події, подає рекомендації щодо подальшого вивчення теми, відповідає на запитання екскурсантів;

- рекламна - подаються відомості стосовно пропозиції інших екскурсій, які пропонуються туристсько-екскурсійним підприємством як пов'язані й такі, що можуть розширити й поглибити знання з теми екскурсії, так і не пов'язані з нею.

Висновок і вступна частина екскурсії не повинні бути занадто довгими й за часом орієнтовно становлять по 5-7 хвилин.

Екскурсанти не в змозі постійно сприймати екскурсійний матеріал, тобто безперервні розповіді і показ на екскурсії недопустимі. Оскільки, сприйняття матеріалу, спочатку знижується, а потім і зовсім припиняється. Для цього в екскурсіях завжди передбачаються паузи.

Паузи бувають двох видів:

- сутнісна - час перерви використовується екскурсантами для обмірковування екскурсійної інформації, самостійного ознайомлення 3 об'єктами, закріплення фактичного матеріалу в пам'яті, фрормулювання власних висновків і запам'ятовування;

- відпочинкова - не несе смислового навантаження, а використовуються екскурсантами для відпочинку, купівлі сувенірів, прийому їжі, задоволення санітарних потреб.

Паузи варто планувати в періоди переходів та переїздів, в хвилини, вільні від показу і розповіді, між висвітленням різних питань однієї підтеми. Під час паузи екскурсовод замовкає і також має короткочасний відпочинок. Паузи існують у кожній екскурсії і плануються залежно від маршруту. Більше пауз 
буває в заміських екскурсіях.

Подана технологія розробки екскурсії стосується будь-якого виду, форми проведення роботи, в тому числі і еколого-екскурсійної діяльності.

Отже, соціальні запити сьогодення, здобутки науково-технологічної галузі вимагають осучаснення методології, нового інструментарію й процесуального впровадження стратегічного екологічного контенту. Реалізація цілей стратегії сталого розвитку передбачає екологізацію усіх сфер життєдіяльності людини. Екологізація $€$ парадигмою сьогодення. Розширення інформаційного поля одна з умов ефективності освіти 3 питань навколишнього середовища та розвитку. Відомо, нерозуміння взаємозв'язку між діяльністю людини і станом довкілля існує понині, що, частково, пояснюється неточною й недостатньою поінформованістю населення. Еколого-екскурсійна діяльність розглядається як ефективний шлях, здатний забезпечити вимоги суспільства в частині просвітницької й освітньої діяльності щодо екологізації. Наступним етапом варто дослідити можливості використання сучасних методів, прийомів і засобів у роботі екологічного просвітництва, реалізувати їх. Особливістю суспільного розвитку $є$ інформатизація простору. Доцільно звернути увагу на застосування інформаційних програм, медіа-, тощо у здійсненні проектів екологоекскурсійної діяльності як одного 3 ефективних шляхів оптимізації інтелектуально-когнітивної складової особистості людини.

\section{Використана література:}

1. Дашевська I. М., Томкович О. І. Інтерактивні методи навчання та їх застосування в екскурсійній діяльності. Вісник Луганського наиіонального університету ім. Тараса Шевченка. Луганськ, 2012. № 4 (239). Ч. 2. С. 129-134.

2. История зарубежной дошкольной педагогики / сост. Н. Б. Мчедлидзе, А. А. Лебеденко, Е. А. Гребенщикова. Москва : Просвещение, 1986. 464 с.

3. Король О. Д. Організація екскурсійного обслуговування в туризмі : навч. посіб. Сучава, Сучавський університет, 2015. 110 c. [Електронний ресурс]. Режим доступу: http://www.geotour.chnu.edu.ua/index.php?page=/ua/07navchproc.

4. Поколодна М. М. Організація екскурсійної діяльності: підручник / Харків. нац. ун-т. міськ. госпва ім. О. М. Бекетова. Харків : ХНУМГ ім. О. М. Бекетова, 2017. 180 с.

5. Програма дій з подальшого впровадження “Порядку денного на XXI століття (“Rio+5”)". Київ : Інтелсфера, 2000. 59 с.

6. Рудейчук М. М. Основи екскурсійної роботи : метод. посіб. Ужгород : Закарпатський центр туризму, краєзнавства, екскурсії і спорту учнівської молоді, 2017. 34 с.

7. Сталий розвиток суспільства: 25 запитань та відповідей. Тлумачний посібник. Київ : Поліграф експрес, 2001. 28 с.

8. Стратегія ЄЕК ООН з освіти в інтересах збалансованого розвитку. - Бібліотека Всеукраїнської екологічної ліги Серія “Охорона навколишнього середовища”. Київ : “Аспект-Поліграф”. 2006. № 3.

9. Стратегія сталого розвитку (туристична галузь): навч. посіб. / В. М. Ісаєнко, К. Д. Ніколаєв, К. О. Бабікова [та ін.]. Київ : НПУ ім. М. П. Драгоманова, 2013. 301 с.

\section{References:}

[1] Dashevska I. M., Tomkovych O. I. Interaktyvni metody navchannia ta yikh zastosuvannia v ekskursiinii diialnosti. Visnyk Luhanskoho natsionalnoho universytetu im. Tarasa Shevchenka. Luhansk, 2012. № 4 (239). Ch. 2. S. 129-134.

[2] Istoriya zarubezhnoj doshkolnoj pedagogiki / sost. N. B. Mchedlidze, A. A. Lebedenko, E. A. Grebenshikova. Moskva : Prosveshenie, 1986. 464 s. 
[3] Korol O. D. Orhanizatsiia ekskursiinoho obsluhovuvannia v turyzmi : navch. posib. Suchava, Suchavskyi universytet, 2015. $110 \mathrm{~s}$. [Elektronnyi resurs]. Rezhym dostupu : http://www.geotour.chnu.edu.ua/ index.php?page=/ua/07navchproc.

[4] Pokolodna M. M. Orhanizatsiia ekskursiinoi diialnosti: pidruchnyk / Kharkiv. nats. un-t. misk. hosp-va im. O. M. Beketova. Kharkiv: KhNUMH im. O. M. Beketova, 2017. $180 \mathrm{~s}$.

[5] Prohrama dii z podalshoho vprovadzhennia "Poriadku dennoho na KhKhI stolittia ("Rio+5")". Kyiv : Intelsfera, 2000. $59 \mathrm{~s}$.

[6] Rudeichuk M. M. Osnovy ekskursiinoi roboty : metod. posib. Uzhhorod : Zakarpatskyi tsentr turyzmu, kraieznavstva, ekskursii i sportu uchnivskoi molodi, 2017. $34 \mathrm{~s}$.

[7] Stalyi rozvytok suspilstva: 25 zapytan ta vidpovidei. Tlumachnyi posibnyk. Kyiv : Polihraf ekspres, 2001. $28 \mathrm{~s}$.

[8] Stratehiia YeEK OON z osvity v interesakh zbalansovanoho rozvytku. - Biblioteka Vseukrainskoi ekolohichnoi lihy Seriia "Okhorona navkolyshnoho seredovyshcha". Kyiv : "Aspekt-Polihraf". 2006. № 3 .

[9] Stratehiia staloho rozvytku (turystychna haluz) : navch. posib. / V. M. Isaienko, K. D. Nikolaiev, K. O. Babikova [ta in.]. Kyiv : NPU im. M. P. Drahomanova, 2013. 301 s.

ГАРМАТА А. Н., ЛАЗЕБНАЯ О. Н., БОНДАРЕНКОЛ. И. ЭКОЛОгО-эКскУрсИоННаЯ деЯтеЛЬНость: методический аспект.

Внедрение в Украине европейских стандартов жизни и выход на ведущие позищии мира предполагает ряд реформ и программ во всех сферах общественной жизни. Среди других важных факторов реализачии стратегии устойчивого развития является направленность на сохранение окружающей среды. Реализаџия стратегии устойчивого развития требует экологизации общества на всех уровнях жизнедеятельности человека. Объективация указанным требует осовремененного прочессуального обеспечения, что основывается на возможных методических, технологических достижении общественного развития. Использование эколого-экскурсионного инструментария с применением информационных методов позволит оптимизировать становление интеллектуально-когнитивного компонента личностного роста человека, будет способствовать формированию экоцентрического вектора ее мировоззренческих позиций.

Ключевые слова:экологизация, экскурсионный метод, экскурсия, эколого-экскурсионная деятельность, методика проведения экскурсии, информационный метод.

\section{GARMATA O. M., LAZEBNA O. M., BONDARENKO L. I. Ecological-excursion activity: methodical} aspect.

The introduction of European standards of living in Ukraine and entering the leading positions of the world implies a number of reforms and programs in all spheres of public life. Among other important factors in the implementation of the Sustainable Development Strategy is the focus on environmental protection. The implementation of a sustainable development strategy requires the greening of society at all levels of human activity. The objectification of the above requires up-to-date procedural support based on the possibilities of methodological and technological achievements of social development. The use of ecological-excursion tools with the use of information methods will optimize the formation of intellectually-cognitive component of human personal growth, will contribute to the formation of ecocentric vector of his outlook.

Keywords: ecology, excursion method, excursion, ecological excursion activity, excursion technique, information method. 